\title{
The Current State and Future of the European Danube Region Strategy (EDRS)
}

\section{Summary}

The European Danube Region Strategy (EDRS) is a macro-regional development strategy and Action Plan for regions and countries in the Danube River Basin. Its purpose is to regulate the sustainable development of the Danube macro-region and the protection of its sites, landscapes and cultural values. The strategy plays a particularly important role in promoting sustainable transport, in linking energy systems, in environmental protection, and in the preservation of water resources in order to improve the business environment and offer a wide range of opportunities for economic development in the macro-region. This study presents the European Danube Region's Strategic Action Plan and its priorities, paying special attention to Hungarian activities and businesses. The results of the EDRS are reflected in the international coordination and in the preparation of projects and major developments through resource allocation on the level of the EU and in Hungary. The author gives an overview of the future of European macro-regional strategies and the EDRS.

Journal of Economic Literature (JEL) codes: D04, E61, P25, R58.

Keywords: macroregional strategies, development policy coordination, regional economy, regional planning.

Dr Lajos Veres, Professor, University of Dunaújváros (veresl53@gmail.com). 


\section{INTRODUCTION}

In the Presidency Conclusions of 18 June 2009, the European Council requested the Commission to prepare an EU Strategy for the Danube Region (EUSDR). ${ }^{1}$ The Commission adopted a Communication on 8 December 2010 (with an Action Plan identifying specific actions and examples of projects in 11 priority areas), ${ }^{2}$ which was then endorsed in April 2011 by the Council. ${ }^{3}$

The European Danube Region Strategy (EDRS) was adopted by the Hungarian Presidency on 30 June 2011 in Budapest. It was the second EU macro-regional strategy, which followed the EU Strategy for the Baltic Sea Region. A first Report to the European Parliament, the Council, the European Economic and Social Committee and the Committee of the Regions concerning the EUSDR was issued on 8 April 2013. ${ }^{4}$

\section{Figure 1: EDRS countries}

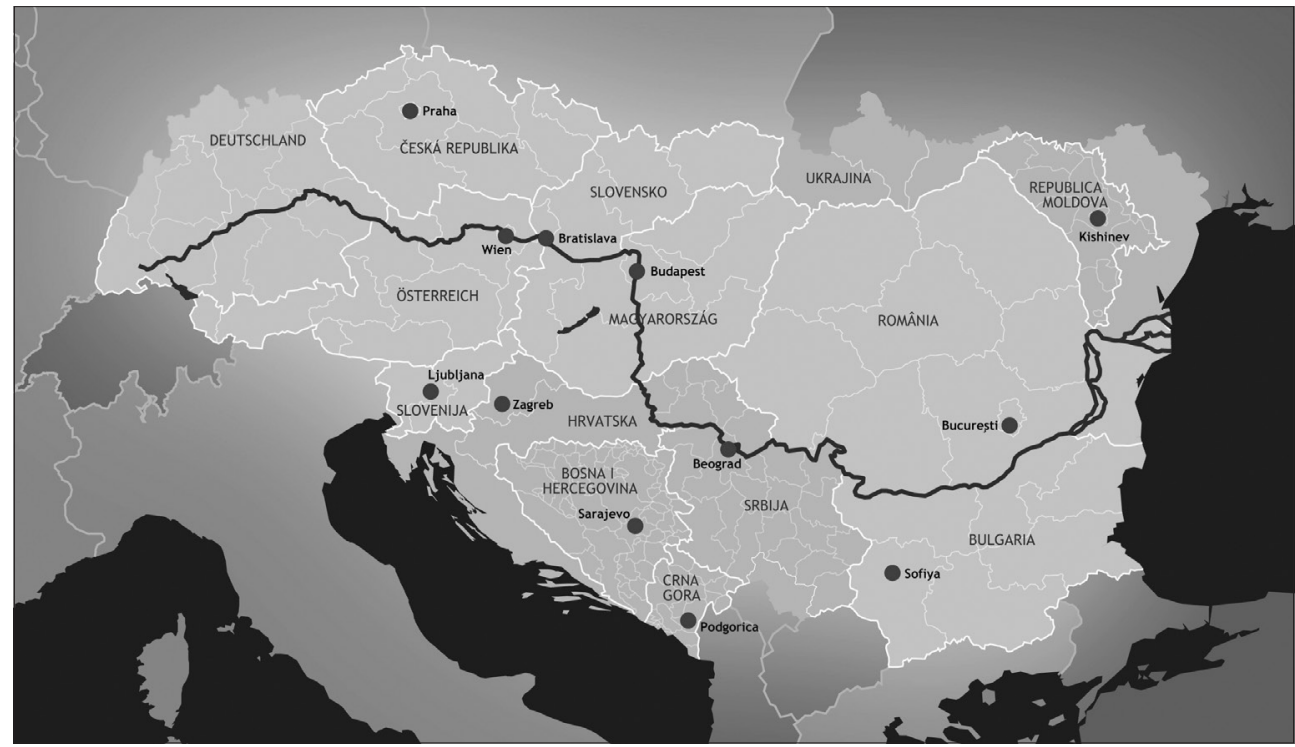

Source: www.danube-region.eu/

Countries in the EDRS area:

- 9 EU Member States: Austria, Bulgaria, Croatia, Czech Republic, Germany (Baden-Württemberg, Bayern), Hungary, Romania, Slovakia, Slovenia

- 3 additional connecting countries: Bosnia and Herzegovina, Montenegro and Serbia

- 2 neighbours : Moldova and the Ukraine (4 districts)

A complex approach to the Danube area required new methods for the development of the strategy. As a versatile corridor, the Danube River emphasizes the transnational character of strategy creation. Obviously, the Danube also areas appear in Hungary's National Development Plan documents and policies. 


\section{Lajos Veres - The Current State and Future of the European Danube Region Strategy}

National interests may differ from country to country, in specific issues (Lentner, 2007). In addition, different priorities may be included in the separate development programmes and strategies for the Danube NUTS2 and NUTS3 regions. The DanubeCities (ESPON categories) are developing at a rapid pace, especially in the metropoli$\tan$ areas.

Therefore, the elaboration of the Danube Strategy could not be part of a traditional planning process with a designer workshop finding the optimum vision, collects policy expectations and sets professional requirements. A continuously (or at least regularly) operating international design system was needed. Some of the projects in the INTERREG programmes III and IV indicate positive experiences in this area (Veres, 2010a; 2010b). Demand has increased for forums not created for unilateral information and opinion formation but for the purpose of discourse. This was the purpose, for example, of the Danube-Region Cohesion, Interregional International Scientific Conference organised at the University of Dunaújváros already on four occasions.

The Danube is an important link between the European Union and the countries acceding the EU. Consequently, the European Union also plays a major role in the development of the Danube as one of Europe's most important and busiest waterways. A series of international scientific conferences provided opportunities in Hungary and in the neighbouring countries for the participants to familiarize themselves with the social and economic as well as natural developments taking place along the Danube, and to identify possible goals and directions in improvement. This allows the Danube countries, regions and communities can play a significant role in Europe's development (Veres, 2010c).

The discourse-triggering conferences resulted in the exploration and enhancement of opportunities for cooperation between the countries along the Danube, in the generation of new joint projects, and in the expansion and promotion of international and interregional relations (Veres, 2016).

\section{Summary of the EDRS Action Plan}

In early June, 2010, DG REGIO, the body in charge of the preparation of the Danube Region Strategy on behalf of the European Commission, delivered a consultative version of the Action Plan for the Member States on the basis of previously submitted national contributions and stakeholder conferences. This was the basis for the subsequent bilateral and multilateral negotiations with Member States and for the legitimacy of actions selected for the cooperation (European Commission, 2010).

The EU Strategy for the Danube Region was published in two documents: a Communication from the European Commission to the other EU Institutions, and an accompanying Action Plan, which complements the Communication. The projects are considered to be illustrative, providing examples of project types or approaches encouraged in general. The essence of the procedure is that the actions ${ }^{5}$ or projects $^{6}$ 
included in the Action Plan are implemented by the Member States and the stakeholders on the basis of the subsidiarity principle.

The Action Plan sets clear priorities, and provides the information required for implementation and follow-up. The priorities are broken down into well-defined actions, with sample project proposals for the presentation of the supporting actions. As a common feature of the actions specified in the Action Plan, they all support the existing EU policies, including the EU's strategic guidelines outlined in the EU 2020 document, the integrated approach based on the principles of sustainability, social cooperation and a number of other effective EU regulations.

Despite the fact that the Action Plan serves stability for a certain period, the thematic priorities ${ }^{7}$ may change over time, and so the actions and projects may also be reviewed, transformed or replaced (this is called. a "rolling" plan).

\section{The MAIN CONCLUSions of The AGtion Plan IN THE ORIGINAL STRUCTURE}

\section{Improving the connectivity of transport links and energy systems}

Improving accessibility and mobility

Mobility goes beyond technical aspects and infrastructure; it includes organisational issues, meeting transport-related demand, regional development and even personal life styles. Most of the problems affecting the system are caused by a lack of coordinated planning and implementation. In the case of appropriate developments, the Danube can become a cost effective transport corridor. In terms of inland navigation, goods traffic on the Danube only amounts to $10 \%$ of freight forwarding on the Rhine, and consequently, it can be increased by improving intermodality or by using higher-standard assets. Development needs are affected by the fact that the Danube is not navigable throughout the year, its ports need improvement, and neither the fleet, nor the personnel are sufficient. The road and rail systems are inefficient, some elements, including border-crossing points, are missing.

Integration of energy systems, energy efficiency and renewable energies

As the power supply systems are made of power networks and markets, it is important to ensure that disadvantaged and remote regions also have access to the Trans European Energy Networks programme (TEN-E). Energy security, diversification and effective governance are important factors. In addition, the Structural and European Agricultural Fund for Rural Development provide good funding opportunities for projects, in particular for the decentralised production of energy from local renewable sources, and for research networks. Market organisation and the actions taken to improve cooperation help to ensure the security of supply, balance supply and demand more effectively, and exploit the economies of scale on investments. In order 


\section{Lajos Veres - The Current State and Future of the European Danube Region Strategy}

to improve energy efficiency, market resources must be managed in an integrated manner, and the security of supply can be increased by reducing energy needs and increasing the share of energy produced in the Danube Region.

Environmental protection, the protection of water resources and risk management

Conservation and maintenance of biodiversity, landscape, air and soil quality

The natural heritage along the Danube is of European significance. Over the past few decades its vulnerability has increased. For this reason, a number of environmental directives and legislative acts were adopted by the EU and compliance is a key issue. Decline in the number of native species and natural habitats (deforestation, urbanization, intensive agriculture, hydropower generation, etc.) is a major problem to be solved. The concerted management of protected areas, linking habitat systems, and expanding and exchanging knowledge increase the sustainable use of natural resources, and raise environmental awareness. The method of using land is of key significance for water and soil protection. Appropriate action to reduce air pollution can only be taken if a single database of the emitters is compiled.

\section{Maintaining and improving water quality}

As several countries share water bodies, their protection is a joint responsibility and requires international and intersectoral cooperation.

The Danube Commission (ICPDR ${ }^{8}$ ), established to enforce the Danube River Protection Convention signed in Sofia in 1994, has a key role in the implementation of the EU Water Framework Directive aimed at restoring the good condition of waters and in the drawing up of river basin management plans. Similar partnerships have also been established for tributaries, such as the Sava and the Tisza. In the deteriorating water quality of the Black Sea, The contamination of the Danube contributes most to the deterioration of Black Sea water quality.

The Danube River Management Plan and the supporting research, monitoring and analysis have identified four main challenges to water quality across the Danube Basin (surface and groundwater, chemical and ecological status).

\section{Management of risks caused by nature and by human activity}

The extreme weather conditions caused by the climate change all around Europe including the Danube Region call for a solution. The frequency of floods, droughts, erosion and drift ice is expected to increase, and directly threaten the population and the economic actors. In addition, in the Danube Region, the high number of industrial risks are associated with the occurrence of permanent environmental risks. In the Danube Region there are many flood-risk areas. Climate change is expected to further increase extreme water flows and will also affect water supply. Therefore, common procedural 
rules should be developed to prevent and respond quickly to disasters, linking participants in risk management. The objective is the development of a Climate Adaptation Strategy for the Danube Region with the involvement of tourism, water management, navigation and agriculture, and to implement an international Flood Risk Management Plan under the leadership of ICPDR. In relation to floods and climate change, it is important to improve the procedures of regional planning and construction regulation and to exchange experiences and best practices between communities.

\section{Development of social, economic and human resources}

\section{Knowledge and innovation}

In terms of the level of innovation development, there is a considerable northwest-southeast division in the Danube Region. Major differences are shown primarily in the intensity of cooperation, partnership, the capital supporting innovation, and corporate investments in R\&D. A general problem throughout the area is that innovation projects are underfunded, and government support and highly qualified human resources are missing. Although in the field of research, bilateral cooperation between universities and research institutions has traditionally been intensive, there is no system for multilateral cooperation. Joint research and educational collaborations can be developed on a geographical basis.

\section{Competitiveness and business support in the Single Market}

The greatest challenges in the region are the different levels of framework conditions for competitiveness and entrepreneurship. Through boosting the institutional capacities and industry associations to support businesses, the conditions can be created locally for innovation. Macro-regional cooperation is needed to bring the Single Market to completion, particularly in services.

Strengthening international cooperation is crucial in the case of countries at different stages of development and with various innovation environments. To this end, the "cluster approach" should be preferred, and the system should be built on a map of the existing clusters. It is important to use the opportunities given in the framework of the European Research Area (ERA) cooperation.

\section{Information society}

The information society is a source of cohesion and environmental sustainability. It promotes the adaption of public services to user needs (e.g. e-commerce, e-governance, ehealth, e-education / e-learning), provides information to citizens, and increases the number of innovations and marketability.

Compared to countries located elsewhere in the EU27, those in the Danube Region have insufficiently developed information societies. The number of computers 


\section{Lajos Veres - The Current State and Future of the European Danube Region Strategy}

at homes, at enterprises and in the public sector need to be increased, broadband coverage should be extended, especially in rural areas, and the e-content and accessibility, such as e-government, e-health, e-education, e-commerce, e-social inclusion need to be improved.

\section{Full use of human resources in the Danube Region}

Due to the decreasing number of births the population is decreasing in the region, and the ratio of highly skilled workers is generally lower than in other countries of the EU27. These make the better use of human resources imperative. In the region the mobility of researchers and students, called "knowledge mobility", is also lower than in the other parts of Europe. Labour mobility is particularly important in order to resolve the legal and administrative issues related to social security and the recognition of qualifications. It is important to promote labour market integration through closer cooperation between labour market organisations, including the coordination of strategies and the exchange of information. In order to increase the exchange of researchers, students and physicians and to reduce one-way migration flows, cooperation and coordination must be intensified between primary, secondary and higher educational organisations, and the mutual recognition of professional qualifications and degrees must be facilitated.

\section{Creation of an Inclusive Danube Area}

In Europe, $80 \%$ of the Roma population live in the Danube catchment area. Attempts at their social integration have frequently been made solely on the basis of action against discrimination. However, social and economic exclusion and territorial segregation are equally important factors. A higher level of awareness and a new monitoring system can support the work of authorities. Particularly important are the projects that bring the members of the Roma community together with the majority of the society.

\section{Promotion of tourism and the Danube Regional culture}

The Danube Region comprises a wide range of diverse communities with different histories, cultures, ethnicities, religions, markets, societies and states. In accordance with various international conventions concluded in the field of culture (e.g. by UNESCO), inclusion, openness, acceptance and mutual respect for values must be promoted. Linked partly to culture and heritage protection, tourism increasingly contributes to economic growth. For this reason, there is an increasing demand for positioning the Danube Region and for the creation of a common identity in tourism. The relationship between different nationalities fosters creativity, and an appropriate basis for innovation and economic development. A cultural approach to tourism improves the attractiveness of the area both for the local people and to the tourists. 
Development of governmental systems

Improving institutional capacities and cooperation

The countries of the Danube Region have different legal traditions, more or less traditions, transparency, democracy, market economy and, in general, political stability. In terms of institutional capacity, there are major differences between the individual countries, public and civil sectors, urban and rural areas, which also affect the political ability to enforce the law. As a closer cooperation in the Danube Region and the exploration of growth potentials depend heavily on trust between the cooperating partners, a clear and transparent regulation, the division of responsibilities the assignment of competences to institutions at various levels, and the facilitation of information flow at all levels are necessary.

\section{Security}

Economic integration and cross-border trade carries the risk of increase in organised crime. The prerequisites of development in the countries along the Danube include peace, security and economic prosperity, which need to be underpinned by law, fight against corruption and organised crime, and the prevention of illegal migration and border crossings. The differences between legislations, policy diversity, and the long and cumbersome legal harmonization are conducive to organised crime, and this is why the dissemination of good practices has a significant role.

The EDRS adopted in 2011 on the technical basis of the Action Plan eventually identified 11 priority areas (Table 1$)$.

Table 1 shows that Hungary played an important role in coordination and was assigned priority areas PA2, PA4, PA5, representing a professional challenge and responsibility, and requiring increasing cooperation.

\section{REPORT TO THE NATIONAL ASSEMBLY ON THE IMPLEMENTATION OF THE EDRS}

On 2 March 2015, the European Affairs Committee of the Hungarian National Assembly heard a report about the current status, achievements and conclusions of the implementation of the European Danube Region Strategy. The report was made by István Joó, Minister of State responsible for the implementation of the Danube Region Strategy. ${ }^{9}$

Special attention was paid to the experiences obtained during the achievement of the Hungarian objectives:

- One of the important objectives was to have the highest possible number of tenders under Hungarian leadership in connection with the Danube Strategy in order to gather information and knowledge in the framework of international projects and to help our companies improve their position in various markets. 


\section{Lajos Veres - The Current State and Future of the European Danube Region Strategy}

Table 1: EDRS pillars and priority areas

\begin{tabular}{|c|c|c|c|c|c|}
\hline \multicolumn{6}{|c|}{ Policy coordination development along four pillars and priority areas 11} \\
\hline \multicolumn{3}{|c|}{ Connecting the Danube region to other regions } & \multicolumn{3}{|c|}{ Greating prosperity in the Danube region } \\
\hline $\mathrm{PA} 1 / \mathrm{a}$ & $\begin{array}{l}\text { Mobility - inland } \\
\text { waterways }\end{array}$ & $\begin{array}{l}\text { Austria and } \\
\text { Romania }\end{array}$ & PA 7 & Knowledge society & Serbia and Slovakia \\
\hline $\mathrm{PA} 1 / \mathrm{b}$ & $\begin{array}{l}\text { Mobility - rail, road } \\
\text { and air transport }\end{array}$ & Serbia and Slovenia & PA 8 & Competitiveness & $\begin{array}{l}\text { Baden-Württemberg } \\
\text { and Croatia }\end{array}$ \\
\hline PA 2 & Sustainable energy & $\begin{array}{l}\text { Czech Republic } \\
\text { and Hungary }\end{array}$ & \multirow{2}{*}{ PA 9} & \multirow{2}{*}{ People and skills } & \multirow{2}{*}{$\begin{array}{l}\text { Austria and } \\
\text { Moldova }\end{array}$} \\
\hline PA 3 & Culture and tourism & $\begin{array}{l}\text { Bulgaria and } \\
\text { Romania }\end{array}$ & & & \\
\hline \multicolumn{3}{|c|}{ Environmental protection in the Danube region } & \multicolumn{3}{|c|}{ Strengthening of Danube region } \\
\hline PA 4 & Water quality & $\begin{array}{l}\text { Hungary and } \\
\text { Slovakia }\end{array}$ & PA 10 & $\begin{array}{l}\text { Institutional } \\
\text { capacity and } \\
\text { cooperation }\end{array}$ & $\begin{array}{l}\text { Austria and } \\
\text { Slovenia }\end{array}$ \\
\hline PA 5 & Environmetal risks & $\begin{array}{l}\text { Hungary and } \\
\text { Romania }\end{array}$ & \multirow{2}{*}{ PA 11} & \multirow{2}{*}{ Security } & \multirow{2}{*}{$\begin{array}{l}\text { Bulgaria and } \\
\text { Germany }\end{array}$} \\
\hline PA 6 & $\begin{array}{l}\text { Biodiversity, land, } \\
\text { air and soil quality }\end{array}$ & $\begin{array}{l}\text { Bavaria and } \\
\text { Croatia }\end{array}$ & & & \\
\hline
\end{tabular}

Source: Jenei, 2017

Figure 2: Financing toolkit relevant and available for the Danube Region Strategy in Hungary

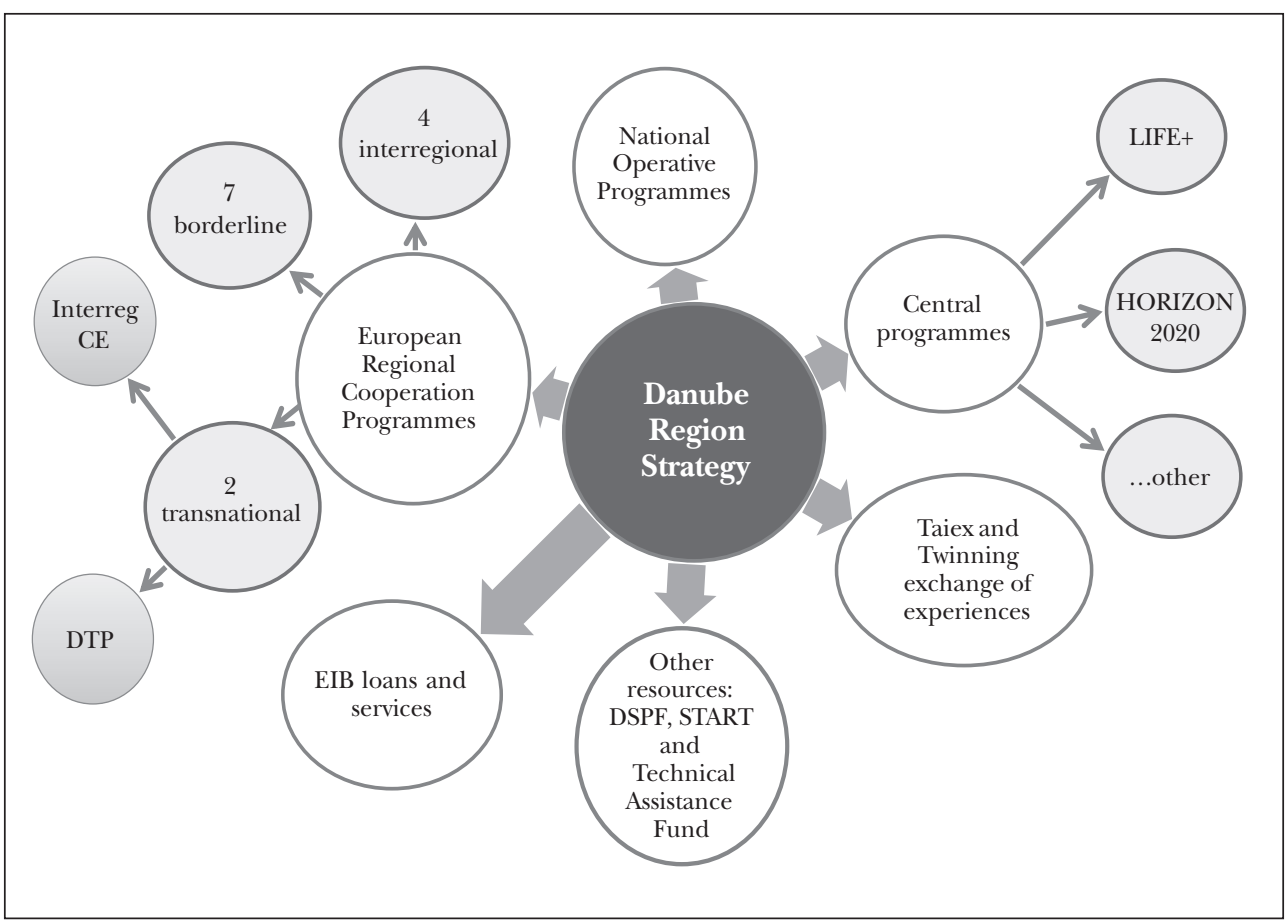

Source: Jenei, 2017 
- Hungary has outstanding knowledge and experience in water management, and macro-regional cooperation provides an organised framework for transferring this expertise to countries with relatively less experience in this area, whether in the Western- Balkan, or east of us.

- The third objective was to use the instruments of the strategy to promote Hungarian water diplomacy efforts. In the post-2011 period, there was a successful cooperation between experts engaged in the management of the Danube River and those working with the Mekong River. Increasing interest is shown in Hungarian water management mainly in Asia. Hungary was given an outstanding opportunity to guide water management activity within the framework of the strategy.

\section{Achievements}

The Danube Region Strategy has been efficiently integrated in the 2014-2020 development period, and the considerations of the Danube Region Strategy have appeared everywhere from the Partnership Agreement through various funds used in Hungary to operational and cross-border cooperation programmes.

Hungary has retained a leading position obtained when this cooperation began during its presidency in 2011.

- Strategic partnership was established with Germany, in particular the BadenWürttemberg region, with the Czech Republic and with non-EU countries.

- The Strategy has been highlighted in various operational programmes, in different funds and as a new element in bilateral cooperation. Recently, this type of cooperation has been established with Baden-Württemberg, Bavaria, Croatia, Moldova and Serbia, and joint economic committees or joint intergovernmental committees have had sessions in this framework.

- The Danube Transnational Programme was set up in Budapest, and raised more than EUR 250 million for the achievement of the objectives and projects of the Strategy in the next period. Its managing authorities and the technical secretariat operate in the framework of the Ministry for the National Economy.

- As an important achievement, the criteria, objectives and projects of the Danube Region Strategy have appeared in local planning procedures (Pest County Council, Voivodina and Southern Hungarian counties).

- As an added value included in the macro-regional approach, these countries have jointly specified the gas market infrastructure projects that should be implemented from the available financial resources in the 2014-2020 period, and have succeeded in channelling these achievements into the various decision-making procedures of the European Union.

This model has been able to show how the implementation of a particular infrastructure element would affect the price of gas in the individual countries of the Danube Region. The construction of a gas storage facility can be highlighted as such a forward-looking example. Almost all the countries surrounding Hungary or located in the Danube Region (only those that are EU Member States) have indicated that 


\section{Lajos Veres - The Current State and Future of the European Danube Region Strategy}

they would like to implement gas storage building projects using EU funds in the 2014-2020 programming period.

The relevant analyses have revealed that at the moment there are 4 billion cubic meters of excess capacity, and if the anticipated developments are implemented, this will increase to 9 billion cubic meters.

- Based on the Biomass Action Plan of the Danube Region, a macro-regional project has been elaborated and will be implemented in the near future with the management of the Szent István University. Eight countries participate in this collaboration related to most important objective, which is to launch and implement the highest possible number of projects with Hungarian management or participation in the 2014-2020 period. We expect to compile a statistical database for bioenergy suitable for supporting investment decisions.

- Based on a comprehensive assessment of the geothermal potentials and development opportunities of the individual countries, the preparation of a macro-regional project has started with the participation of ten countries and will probably be managed by the Hungarian Institute of Geology and Geophysics.

- In support of the integration efforts of non-EU countries, the energy division directed by Hungary held a training course about the energy market in Moldova. Previously, Moldova undertook transpose certain provisions of the European Union's third energy package, however, when it came to putting them into practice, difficulties were encountered. Within the framework of the Danube Strategy it was therefore of paramount importance to implement a knowledge transfer project in Chisianu.

- The Water Quality Priority Area is jointly managed by Hungary and Slovakia. Recently, analyses have been made on the status of buffer zones, waste management, and the use of alternative wastewater treatment techniques. A project may now be launched with Hungarian direction for the management of sediments in the Danube River catchment area. Serious efforts were needed to position the $\mathrm{Bu}$ dapest Technical University the future project manager: Western European countries' unwillingness to admit relevant Hungarian experience and expertise had to be overcome.

The purpose of the project planned to involve six countries is to provide input on the sediment balance to legislators and stakeholder experts as a basis of subsequent decisions. The undesirable deepening of the Danube bed is a well-known fact and grounded solutions may be found to this problem during the project.

Nearly 70 percent of Hungary's water management problems relate to the Tisza River. Previously, international catchment management was managed by the International Commission for the Protection of the Danube River (ICPDR) in Vienna. The handover of the Tisza Office in Szolnok was a major achievement, and this branch will assist the work of the Tisza Group as a coordinating platform.

- Flood control is coordinated jointly by Romania and Hungary. An action plan has been compiled for flood control in the Danube Region. A survey of flood control in all the 14 countries of the Danube Region Strategy has begun with Hungary's management. 
- In the period between 2014 and 2020, the criteria set out in the objectives of the Strategy are enforced in an organised framework. There are best practices and crossborder cooperation programmes inherited from the 2007-2013 period.

As for other opportunities, centrally managed funds are available from Brussels, such as the Life+, the Horizon 2020, and the European territorial cooperation programmes, including transnational programmes, such as the Central Europe Programme and the Danube Operational Programme (see Figure 2).

Many say that a significant portion of these funds were already available in the 2007-2013 period, and, although in a limited amount, they were also available in the last two years. However, it is important to note that partnerships and the frameworks of cooperation which have developed their concepts in accordance with criteria set by the Danube Region Strategy and are actually be able to have access to these resources have only evolved recently.

In order to improve the flow of information, in 2015 a project financing conference was organised by the Hungarian Ministry of Foreign Affairs and Trade for Hungarian stakeholders who wish to implement projects in relation to water management and energy in the next period.

\section{THE NEW ROLE OF MAGRO-REGIONS}

In 2015 the European Parliament made a critical and analytical overview of the new role of macro-regions in the European territorial cooperation (European Parliament, 2015) and concluded that macro-regional strategies have become a crucial concern in shaping the European territorial cooperation in the post-2013 cohesion policy. The European Union is currently implementing two macro-regional strategies: the EU Baltic Sea Strategy and the EU Strategy for the Danube Region. In October 2014, the EU Adriatic and Ionian Strategy was also adopted. In addition, recommendations have been made for and debates are ongoing about the development of similar strategies for other macro-regions, especially coastal ones, the Alpine, the Carpathian, the North Sea, the Black Sea, the Western and Eastern Mediterranean Sea and the Atlantic Arc regions.

\section{Developments in concepts and legislation related to macro-regional cooperation}

The European Parliament first discussed the conceptual definition of macro-regions and macro-regional strategy, the latter called an increasingly important area of governance for European territorial cooperation. Macro-regional strategies are important tools not only for regional policies but also for foreign policy. The future of macro-regional strategies are discussed against conflicting views on post-2013 cohesion policy and a changing regulatory framework. The European Parliament's comments clearly point towards support to a territorial and contractual approach in macro-regional cooperation, in line with the Europe 2020 agenda. It was noted that the added value of macro-regional strategies lies in promoting the involvement of 


\section{Lajos Veres - The Current State and Future of the European Danube Region Strategy}

neighbouring countries, the creation of territorial synergies and the reduction of regional disparities.

The macro-regional strategies under consideration are analyses of the Carpathian Region, the North Sea, the Black Sea, the Atlantic Arc and the Strategy for the Western and Eastern Mediterranean. At the current stage, the concepts of certain strategies have not yet been clearly linked to specific needs or specific actors / partial areas, while in the case of other strategies, due to the high level of social and economic cohesion, there is still considerable doubt concerning the need for macro-regional cooperation. Contrary to other strategies, the feasibility of macro-regional cooperation can be questioned because of the social and economic inequalities and political instability.

The classification of macro-regional strategies is based on an in-depth assessment of the need for cohesion as a means of achieving a macro-regional level of social, economic and territorial cohesion as a tool for cohesion in post-2013 cohesion policy. According to the analysis, macro-regional strategies should be divided into three groups: 1) macro-regional strategies that function as possible means of the EU's foreign policy (Mediterranean and Black Sea Strategies); 2) macro-regional strategies used for combatting development inequalities (Danube Region, Baltic Sea, Adriatic, Ionian and Carpathian regions) and 3) macro-regional strategies that serve as potential tools for exploiting territorial synergies (Alpine, Atlantic and North Sea strategies).

\section{Conclusions and policy recommendations}

Added value: The added value of macro-regional strategies for European territorial cooperation and cohesion policy needs to be assessed on the basis of the nature of the reviewed macro-region. According to the three elaborated approaches, the different categories of macro-regional cooperation classified in different categories are expected to have different added values.

Monitoring and evaluation: The preliminary assessment of political and financial needs and capabilities should be given priority in assessing the feasibility of future strategies;

Technical assistance: The European Parliament should continue to provide financial support to transnational activities, while also carefully assessing in this respect what and how they can fulfil in the next few years;

Regulatory framework: The European Parliament should examine the idea of conditionality of macro-regional cooperation and the usefulness of European Grouping of Territorial Cooperation in macro-regional strategies in greater depth in the coming years.

\section{Evaluation of Progress in the Danube Strategy}

Numerous projects were launched or improved as a result of the EUSDR. These include: the master plans on Fairway rehabilitation and maintenance and on LNG navigation; the creation of nature protection networks and the development of common 
methodologies for the assessment and management of natural risks due to the climate change; and the setting up of a network for improving security on the Danube River (European Commission, 2016).

The EU Strategy for the Danube Region has clearly improved cooperation culture, linking stakeholders and dovetailing existing institutions to share knowledge and experience. The ministers of transport at the Ministers' Meeting of the Danube Region received high-level political support to ensure better management in Danube shipping. The achievements of the cooperation culture and activity shown as an important goal in the Danube Region Strategy also fed through as spectacular results in automotive industrial cooperation. The experience gained in the European Union and more specifically, in the Danube Transnational Programme has contributed to the development of a Cooperation in Automotive Higher Education and Research in Hungary, the evolution of a coordinated innovation activity, and network cooperation (Tóthné Borbély, 2013).

The Danube Financing Dialogue is an example of a match-making platform offered by the strategy for project promoters and financing institutions to discuss issues and identify suitable solutions related to financing projects in the region (Lentner, 2015a).

The EUSDR has also made the governance system more effective by strengthening coordination between policies and institutions at a national level. It has facilitated reaching out to relevant stakeholders at both national and local levels, and continued dialogue with civil society organisations (Lentner, 2015b).

Another important area where the EUSDR has made a genuine contribution included the EU enlargement and neighbourhood policy agendas. It has helped to intensify thematic cooperation with the five participating non-EU states and to bring stability to the area through solid networks and partnerships. Relevant initiatives include the setup of the first European Grouping of Territorial Cooperation with a nonEU country (Hungary and Ukraine), and the establishment of a new coordination scheme in 2015 to allow Moldova to participate in the strategy. Serbia has also taken an active part in coordinating two of the strategy's priority areas.

The implementation of the EUSDR has been supported by the Danube Transnational programme. The latter covers the same geographical area, provides financial support to specific transnational projects and supports the strategy's governance. In 2014, the 14 participating countries jointly set up the Danube Strategy Point (DSP), which became operational in June 2015. The DSP has mainly been active in monitoring, communicating and providing support to priority area coordinators and to cooperation between priority areas.

\section{Challenges}

Irrespective of promising initial achievements, the EUSDR would benefit from a number of specific policy and operational measures, such as the continued integration of the transport and energy infrastructure, actions to counter water pollution, natural risks, 


\section{Lajos Veres - The Current State and Future of the European Danube Region Strategy}

common labour market and education policies, competitiveness measures, in particular for SMEs, and measures addressing demographic challenges and brain drain. The security dimension remains important as is the need to develop public administration capacities.

In addition, new challenges have been faced in the past two years, for example relating to migration flows, global security and terrorism (Veres, 2017).

The administrative capacity available for the arrangement of implementation and for improving cooperation remains an issue, particularly in non-EU countries. This still requires appropriate responses at both national and regional levels.

\section{Notes}

1 European Council Conclusions of 19 June 2009, point 34: "It... invites the Commission to present an EU strategy for the Danube Region before the end of 2010".

2 Communication from the Commission concerning the European Union Strategy for the Danube Region. 8.12.2010, $\mathrm{COM}(2010) 715$.

3 Conclusions of the General Affairs Council, 13 April 2011 and Conclusions of the European Council, 23-24 June 2011.

4 Report from the Commission concerning the European Union Strategy for the Danube Region. 08.04.2013, COM(2013) 181 final.

5 The action requiring intervention by states and stakeholders is a priority is in line with the objectives of a priority (project) area. This may include a new approach, improved policy coordination, and an objective to be achieved by the given state's own methods, and it does not necessarily require funding. Every action is based on the current EU competences and the expectations arising from the EU regulations. Examples: new approach, removing phosphates from detergents, improving policy coordination, agreement on a joint position during the review of the TEN-T and TEN-E networks.

6 A "project" is a specific action that has a start and an end date, and requires funding, a project leader and partners.

7 A "priority" is a key theme allowing the macro-regional strategy to contribute to improving the current situation by addressing the most serious problems (challenges) or by a better use of the opportunities. To this end, each priority in this document specifies the conflict areas waiting for a solution.

8 International Commission for the Protection of the Danube River.

9 Jegyzôkönyv az Országgyúlés Európai ügyek bizottságának 2015. március 2-án, hétfơn, 11 óra 00 perckor az Országház fốemelet 66. tanácstermében megtartott ülésrôl. www.parlament.hu/documents/static/ biz40/bizjkv40/EUB/1503021.pdf.

\section{REFERENCES}

European Commission (2010): Európai Duna Régió Stratégia (EDRS) Akcióterv összefoglaló [European Danube Region Strategy (EDRS) Action Plan]. www.hidrologia.hu/mht/letoltes/eu_duna_regio_akciotervmagyar\%20osszefoglalo-1.pdf.

European Commission (2016): Report from the Commission to the European Parliament, the Council, the European Economic and Social Committee and the Committee of the Regions on the Implementation of EU Macro-Regional Strategies. European Commission, COM(2016) 805 final, Brussels, http://ec.europa.eu/regional_policy/sources/cooperate/macro_region_strategy/pdf/report_implem_macro_region_strategy_en.pdf.

European Parliament (2015): New Role of Macro-Regions in the European Territorial Cooperation. European Parliament, http://www.europarl.europa.eu/RegData/etudes/STUD/2015/540349/IPOL_STU(2015) 540349_EN.pdf. 


\section{Civic Review · Vol. 14, Special Issue, 2018}

Jenei, Gábor (2017): A Duna Régió Stratégia általános bemutatása és magyar vonatkozásai [General description of the Danube Region Strategy and its relevance to Hungary]. Project Financing Conference, Budapest, 11 May.

Lentner, Csaba (2007): Scientific Taxonomy of Hungarian Public Finances After 2010. Civic Review, Vol. 13, Special Issue, pp. 21-38, https://doi.org/10.24307/psz.2017.0303.

Lentner, Csaba (2015a): The New Hungarian Public Finance System - in a Historical, Institutional and Scientific Context. Public Finance Quarterly, Vol. 60, No. 4, pp. 447-461.

Lentner, Csaba (2015b): Uncertainty Factors in National Economy Planning - International Effects and Hungary's Outlook Up to 2050. Central European Political Science Review, Vol. 16, No. 62, pp. 9-26.

Tóthné Borbély, Viola (2013): A hálózati együttmúködések szerepe a Duna Stratégiában [The contribution of network cooperation to the Danube Strategy]. In: Veres, Lajos (ed.): III. Duna Térségi Kohézió [Cohesion in the Danube Region]. Cikos Group, Subotica, pp. 70-86.

Veres, Lajos (2010a): A Duna komplex fejlesztése az európai területi kohézió folyamatában [Complex development of the Danube in the European territorial cohesion process]. In: Veres, Lajos (ed.): Duna Térségi Kohézió [Cohesion in the Danube Region]. Cikos Stampa, Subotica, pp. 15-22.

Veres, Lajos (2010b): Donauregionen. INTERREG III/B projekt eredményei, tapasztalatai [Achievements and experiences of the INTERREG III/B project]. In: Veres, Lajos (ed.): Duna Térségi Kohézió [Cohesion in the Danube Region]. Cikos Stampa, Subotica, pp. 49-57.

Veres, Lajos (2010c): The Theoretical Approach of Creating a Danube Strategy. In: Regional Responses and Global Shifts: Actors, Institutions and Organisations. Regional Studies Association.

Veres, Lajos (2014): Theoretical and Methodological Foundations of Making the Danube Tourism Strategy. In: Talabos, István (ed.): Tourism of Danube Area. Cikos Group Publishing Co., Subotica, pp. 4-42.

Veres, Lajos (2016): Nemzetközi stratégiaalkotás a Duna-mente térségében [International strategy building in the Danube Region]. In: Karlovitz, János Tibor (ed.): Társadalom, kulturális háttér, gazdaság [Society, cultural background, economy]. International Research Institute, Komárno, pp. 143-156.

Veres, Lajos (2017): A Kelet-Nyugat Kohézió Európai és globális dimenziói [European and global dimensions of the East-West cohesion]. East-West Cohesion Conference, Studies, Szabadka, pp. 6-17. 